Abstracta Iranicacta Iranica

Revue bibliographique pour le domaine irano-aryen

Volume 25 | 2004

Comptes rendus des publications de 2002

Médias, pouvoir et société civile en Iran. Paris, L'Harmattan, 2001, 167 p.

\title{
Robert Mallet
}

\section{(2) OpenEdition}

1 Journals

Édition électronique

URL : http://journals.openedition.org/abstractairanica/5147

DOI : 10.4000/abstractairanica. 5147

ISSN : 1961-960X

\section{Éditeur :}

CNRS (UMR 7528 Mondes iraniens et indiens), Éditions de l'IFRI

\section{Édition imprimée}

Date de publication : 15 mai 2004

ISSN : 0240-8910

\section{Référence électronique}

Robert Mallet, « Médias, pouvoir et société civile en Iran. Paris, L'Harmattan, 2001, 167 p. », Abstracta Iranica [En ligne], Volume 25 | 2004, document 321, mis en ligne le 15 mars 2006, consulté le 25 septembre 2020. URL : http://journals.openedition.org/abstractairanica/5147 ; DOI : https://doi.org/ 10.4000/abstractairanica.5147

Ce document a été généré automatiquement le 25 septembre 2020.

Tous droits réservés 


\title{
Médias, pouvoir et société civile en Iran. Paris, L'Harmattan, 2001, 167 p.
}

\author{
Robert Mallet
}

1 Inspirée par une idée de Jürgen Habermas selon laquelle la fin de l'État absolutiste correspond à la constitution "d'un espace public » où les citoyens débattraient de l'exercice du pouvoir, l'A. prend les médias, et en particulier la presse écrite dans l'Iran contemporain, comme élément central de son étude afin de détecter l'apparition de cet espace public et de démontrer ses liens dialectiques avec les médias depuis la révolution constitutionnaliste jusqu'à nos jours.

Malgré une problématique de départ fort intéressante, l'A. ne réussit à nous esquisser, dans une démarche purement chronologique, que les grandes étapes de l'évolution laborieuse des médias iraniens. Une évolution affectée, selon elle, par les contraintes de la censure arbitraire des régimes politiques et par la faiblesse structurelle de la société civile.

3 Dans cette démonstration, S. Farkhondeh ne donne, à aucun moment, ni un début d'examen critique du contenu des médias ni un début de l'analyse historique et sociale nécessaire à la compréhension de cette évolution. Elle se contente simplement de calquer les schémas théoriques occidentaux sur ses propres données générales et imprécises de l'Iran pour en mesurer le degré de "liberté » ou de "vérité " presque absolues. De plus, dans son exposé, elle confond les intellectuels (tout en ignorant les musulmans), les militants politiques, les journalistes et le peuple.

4 En somme, le résultat est un travail confus et mal organisé qui ne tient pas ses promesses de départ. 
INDEX

Thèmes : 13.1. Iran

\section{AUTEURS}

ROBERT MALLET

Paris 